\title{
PRELIMINARY ANNOUNCEMENT
}

7th International Symposium on Applied Stochastic Models and Data Analysis

12-15 June 1995, Dublin, Ireland

Sponsor: ASMDA International Society

Contact: Sally McClean, Mathematics Department, University of Ulster, Coleraine, Northern Ireland BT52 1SA

Telephone: + $4426544141 \quad$ Fax: +4426540916

E-mail: bdcg13@.ucvax.ulster.ac.uk

\section{ROLLO DAVIDSON TRUST}

The Trustees of the Rollo Davidson Trust give notice that they have awarded Rollo Davidson Prizes for 1994 to Thomas S. Mountford (University of California at Los Angeles) for his work on interacting particle systems, and to Laurent SaloffCoste (Université Paul Sabatier, Toulouse) for his work on rates of convergence for Markov chains and random walks on finite groups. 


\section{Advances in Applied Probability}

The Editorial Board would like to encourage the submission to the Advances of review papers summarising and coordinating recent results in any of the fields of applied probability.

In addition to these review papers, Advances is also designed to be a medium of publication for (1) longer research papers in applied probability, which may include expository material, (2) expository papers on branches of mathematics of interest to probabilists, (3) papers outlining areas in the biological, physical, social and technological sciences in which probability models can be usefully developed, (4) papers in applied probability presented at conferences which do not publish their proceedings, and finally, (5) letters to the editor on any appropriate topic in applied probability.

Advances now includes a section devoted to stochastic geometry and statistical applications (see the announcement and call for papers in the March 1993 issue).

In short, the main function of Advances is to define areas of recent progress and potential development in applied probability. As with the Journal of Applied Probability, Advances undertakes to publish papers accepted by the Editors within 15 months of their submission; letters to the editor will normally be published more rapidly.

Volume 26 No. 2 of Advances contains the following papers:

\section{Stochastic Geometry and Statistical Applications}

M. N. M. VAN LIESHOUT. Stochastic annealing for nearest-neighbour point processes with application to object recognition

ILYA MOLCHANOV AND DIETRICH STOYAN. Asymptotic properties of estimators for parameters of the Boolean model

JOHN GATES. Shape distributions for planar triangles by dual construction

K. V. MARDIA AND I. L. DRYDEN. Shape averages and their bias

\section{General Applied Probability}

W. G. S. HINES. ESS modelling of diploid populations I: anatomy of one-locus allelic frequency simplices

W. G. S. HINES. ESS modelling of diploid populations II: stability analysis of possible equilibria

G. KALLIANPUR AND J. XIONG. Stochastic models of environmental pollution

PAUL EMBRECHTS AND HANSPETER SCHMIDLI. Ruin estimation for a general insurance risk model

C. TERESA LAM AND R. H. YEH. Comparison of sequential and continuous inspection strategies for deteriorating systems

W. HENDERSON, B. S. NORTHCOTE AND P. G. TAYLOR. State-dependent signalling in queueing networks

J. A. MORRISON. Loss probabilities in a simple circuit-switched network

MARK P. VAN OYEN AND DEMOSTHENIS TENEKETZIS. Optimal scheduling of forest networks with switching penalties

WOJCIECH SZPANKOWSKI. Stability conditions for some distributed systems: buffered random access systems

GUNTER RITTER. On the mean sojourn time of jobs in queues with general service disciplines

SERGEI GRISHECHKIN. GI/G/1 processor sharing queue in heavy traffic

P. KONSTANTOPOULOS AND M. ZAZANIS. Sensitivity analysis for stationary and ergodic queues: additional results

Subscription rates (per volume) for the Advances in 1994 are the same as for the Journal (see inside back cover). A discount of $10 \%$ is allowed to subscribers who order current issues of both the Journal and Advances at the same time direct from the Applied Probability Office. A detailed price list for both current and back issues is available on request.

Cheques made out on US, UK and Australian banks will be acceptable: they should be made payable to Applied Probability, and sent to:

Executive Editor, Applied Probability,

School of Mathematics and Statistics,

The University, Sheffield S3 7RH, UK 


\section{MATHEMATICAL}

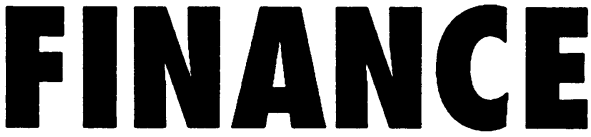

AN INTERNATIONAL JOURNAL OF MATHEMATICS, STATISTICS \& FINANCIAL ECONOMICS

Edited by Stanley R. Pliska

University of Illinois at Chicago

Mathematical aspects of finance theory have, in the past, been scattered throughout publications in finance, economics, mathematics and statistics. Mathematical Finance remedies this by acting as a primary forum for finance researchers, finance practitioners and mathematical scientists. The journal provides clear and concise articles which present the latest theoretical studies in readable and accessible prose.

Also featuring book and software reviews, Mathematical Finance offers new research on the financial applications of statistical and econometric methods; numerical analysis and computational methods; and modern developments in Stochastic Processes, Game Theory, and Optimization Theory.

\section{THE JOURNAL ALSO FEATURES THE MERRILL LYNCH BEST PAPER AWARD...}

As an indication of the journal's committment to outstanding research, and with the generous financial support of Merrill Lynch, the Editors of Mathematical Finance and Blackwell Publishers are offering prizes for the three best papers published in each volume of the journal.

First Prize: $\$ 1,500$ Second Prize: $\$ 1,000$ Third Prize: $\$ 500$

Papers are nominated for the award by the journal's Editorial Board and the winners are chosen by its Advisory Board.

ISSN 0960-1627, Published Quarterly

Subscription information for Mathematical Finance Volume 4, 1994

Individual: ..$\$ 66.50$ (N. America) .......\$76.00 (Rest of World)

Institutional: $\$ 144.50$ (N.America) $\ldots . . . \$ 165.00$ (Rest of Wondd)

*Individual rate available to teaching academics onb; proof of affiliation required.
Journals Dept.

Blackwell Publishers

238 Main Street

Cambridge, MA 02142

or Call Toll-Free (800) 835-6770

Internet: blkwell@worldstdcom 


\section{New publication for 1994 \\ Studies in Applied Probability}

We are pleased to announce the forthcoming publication of Studies in Applied Probability, a Festschrift in honour of Lajos Takács, one of the most versatile and original contributors to the theory of stochastic processes. Thirty-nine internationally known authors have contributed 26 papers reflecting Lajos Takács' wide-ranging influence on applied probability in its widest sense. The book is divided into six parts containing papers on epidemic processes, probabilistic methods, queueing theory, random walks, statistical studies and stochastic processes.

This book will be of interest to research workers specializing in statistical studies, operations research, computer engineering, telecommunications and epidemiology.

The contributors to this volume are:

Alejandro D. de Acosta, Mátyás Arató, U. Narayan Bhat, Simeon M. Berman, N.H. Bingham, W. Böhm, Yuan S. Chow, J.W. Cohen, Endre Csáki, D. J. Daley, Persi Diaconis, Jewgeni H. Dshalalow, Janos Galambos, J. Gani, Joseph Glaz, Peter W. Glynn, C.C. Heyde, J. Keilson, Min-Young Lee, Gérard Letac, Norihiko Miyawaki, S.G. Mohanty, Richard E. Nance, Joseph Naus, M.F. Neuts, N.U. Prabhu, András Prékopa, Ron Pyke, Malgorzata Roos, L.D. Servi, Mehrdad Shahshahani, Masaaki Sibuya, Donatas Surgailis, Ushio Sumita, Ryszard Syski, L.C. Tang, Sylvan Wallenstein, Ward Whitt and Wojbor A. Woyczynski.

This book also includes an appreciation of Lajos Takács and a complete list of his publications to date.

Studies in Applied Probability (Journal of Applied Probability Special Volume 31A). Edited by J. Galambos and J. Gani ISBN 0-902016-04-0 $240 \times 170 \mathrm{~mm}$ hardback. c. 400pp. Illustrated. Available June 1994 . Price: $£ 25.00 /$ US $\$ 37.50 / \$ A 55.25$.

Please send orders, accompanied by payment to APPLIEd Probability, to: Applied Probability, School of Mathematics and Statistics, University of Sheffield, Sheffield S3 7RH, UK.

Telephone: +742824269

Fax: +742729782 


\section{SUBSCRIPTION RATES}

Subscription rates (post free) for the 1994 volume of the Journal are as follows:

US\$168.00; \$A222.00; $£ 105.00$ for libraries and institutions;

US $\$ 56.00 ; \$ A 74.00 ; £ 35.00$ for individuals belonging to a recognised scientific society.

Members of the London Mathematical Society should apply direct to the Secretary of the Society for copies of the Journal.

Please send all enquiries to: Applied Probability, School of Mathematics and Statistics, The University, Sheffield S3 7RH, UK.

We can provide back issue prices on application. Cheques, money orders, etc. should be made out to APPLIED PROBABILITY. Payment is accepted in US, UK or Australian currency.

\section{NOTES FOR CONTRIBUTORS}

Papers published in the Journal are of two kinds:

(1) research papers not exceeding 20 printed pages;

(2) short communications of a few printed pages in the nature of notes or brief accounts of work in progress.

Review papers, longer research papers and letters to the editor are published in Advances in Applied Probability, a companion journal. (Note: Letters relating specifically to papers which have appeared in the Journal of Applied Probability will continue to appear in the Journal.)

The editors may publish accepted papers in either journal, according to the space available, in order to meet the 15 -month deadline in publication referred to below.

\section{Submission of papers}

Papers submitted to the Applied Probability journals are considered on the understanding that they have not been published previously and are not under consideration by another publication. Papers will not be reprinted without the written permission of the Trust. It is the policy not to accept for publication papers which cannot appear in print within 15 months of the date of receipt of the final version. Fifty reprints of each paper will be provided free; additional reprints are available at cost.

Papers should be written in English or French; papers in other languages may be accepted by the editors, but will appear (subject to the author's agreement) in English or French translation. Please supply three double-spaced hard copies, at least one of which should be printed on one side of the paper only. The paper should include: (1) a short abstract of approximately 4-10 lines giving a nonmathematical description of the subject matter and results; (2) list of keywords detailing the contents for the purpose of computerised information retrieval; (3) primary and secondary classifications according to the 1991 Mathematics Subject Classification, to be found in the 1990 Annual Index of Mathematical Reviews.

Authors are advised to consult The Author's Guide to the Applied Probability Journals when preparing papers for submission. A copy of this guide may be obtained free of charge from the Applied Probability Office.

For efficiency in processing, authors are requested to send all submissions to the Applied Probability Office in Sheffield, rather than to individual editors. The address for all submissions is:

\section{Executive Editor, Applied Probability, School of Mathematics and Statistics, The University, Sheffield S3 7RH, UK.}

\section{COPYRIGHT}

The copyright of all published papers shall be vested in the Trust. When a paper is accepted for publication, the Trust requests the author(s) to sign a form assigning copyright to the Trust. Failure to do this promptly may delay or prevent publication.

Authorisation to photocopy items for internal or personal use, or the internal or personal use of specific clients, is granted by the Applied Probability Trust for libraries and other users registered with the Copyright Clearance Center (CCC) Transactional Reporting Service, provided that the base fee of $\$ 00.70$ per copy, plus .10 per page is paid directly to CCC, 222 Rosewood Drive, Danvers, MA 01923 , USA. $0021-9002 / 94 \$ 00.70+.10$. 


\section{Volume 31 Number 2}

Research Papers

287 S. MERAD AND J. M. MCNAMARA. Optimal foraging of a reproducing animal as a discounted reward problem

301 RICHARD COWAN AND S. N. CHIU. A stochastic model of fragment formation when DNA replicates

309 M. MÖHLE. Forward and backward processes in bisexual models with fixed population sizes

333 THIERRY HUILLET AND ANDRZEJ KEOPOTOWSKI. Sur une procédure de branchement déterministe et ses dérivées aléatoires

348 GEORGE M. TSAKLIDIS. The evolution of the attainable structures of a homogeneous Markov system with fixed size

362 D. J. HARTFIEL. Homogeneous Markov chains with bounded transition matrix

373 HARRI NYRHINEN. Rough limit results for level-crossing probabilities

383 ROCCO BALLERINI. Archimedean copulas, exchangeability, and max-stability

391 JOSÉ A. ADELL AND JESÚS DE LA CAL. Approximating gamma distributions by normalized negative binomial distributions

401 F. PAPANGELOU. On a distributional bound arising in autoregressive model fitting

409 THOMAS H. SPENCER. Generalized Bonferroni inequalities

418 FABRICE GUILLEMIN AND RAVI MAZUMDAR. The Beňes equations for the distribution of excursions for general storage processes

430 SHALER STIDHAM JR. A sample-path approach to Palm probabilities

438 DAVID ASSAF AND ARIELA SHARLIN-BILITZKY. Dynamic search for a moving target

458 ENRICO FAGIUOLI AND FRANCO PELLEREY. Preservation of certain classes of life distributions under Poisson shock models

466 ZHEN LIU AND DON TOWSLEY. Optimality of the round-robin routing policy

476 HO WOO LEE, SOON SEOK LEE, JEONG OK PARK AND K. C. CHAE. Analysis of the $M^{x} / G / 1$ queue with $N$-policy and multiple vacations

497 R. SZEKLI, R. L. DISNEY AND S. HUR. $M R / G I / 1$ queues with positively correlated arrival stream

515 C. OLIVIER AND J. WALRAND. On the existence of finite-dimensional filters for Markovmodulated traffic

526 ROBERT B. LUND. A dam with seasonal input

Short Communications

542 MATS GYLLENBERG, TIMO KOSKI, EDWIN REILINK AND MARTIN VERLAAN. Nonuniqueness in probabilistic numerical identification of bacteria

549 BORIS L. GRANOVSKY AND LIAT ROZOV. On transient behaviour of a nearest-neighbour birth-death process on a lattice

554 HUAIGAO LIU. On Cowan and Mecke's Markov chain

561 JOANNE KENNEDY. Understanding the Wiener-Hopf factorization for the simple random walk

564 ALAN C. KIMBER. An application of random packing to the multiple fracture of composite materials

570 R. M. PHATARFOD. On the transition probabilities of the move-to-front scheme

575 R. P. LITTLEJOHN. A reversibility relationship for two Markovian time series models with stationary exponential tailed distribution

582 TOMASZ EUCZAK AND ZBIGNIEW PALKA. On the clique number of a random overlap graph

589 MARTIN A. WORTMAN AND GEORGIA-ANN KLUTKE. On maintained systems operating in a random environment 